\title{
Głoszenie Chrystusa i jego recepcja w starożytności i dziś w aspekcie przepowiadanej treści
}

Quidquid recipitur ad modum recipientis recipitur

\section{Wprowadzenie}

Poznanie Jezusa Chrystusa stanowi o życiu wiecznym każdego człowieka (por. J 17, 3) i, jak mówi św. Paweł, On jest Głową (Kol 1, 18) i fundamentem życia chrześcijańskiego (1 Kor 3, 11), i jedynym pośrednikiem pomiędzy Bogiem i człowiekiem (1 Tm 2, 5). Chociaż jest ten sam wczoraj i dziś, i na wieki (por. Hbr 13, 8), Alfą i Omegą, Początkiem i Końcem (Ap 21, 6; 22, 13), to kwestia poznania Jego orędzia i decyzji o przynależeniu do grona Jego przyjaciół bądź Jego odrzuceniu aktualizuje się zawsze w życiu konkretnego człowieka i dlatego pozostaje niezmiennie aktualna. Decyzję o przynależności podejmuje się przecież nie ze względu na samo imię, ale przede wszystkim na treść, jaką ono z sobą przynosi. To właśnie treść orędzia Ewangelii Jezusa różnicowała od samego początku Jego wyznawców i pobudzała do 
kontrowersji teologicznych. Nic dziwnego, że głoszenie autentycznej i integralnej Ewangelii Jezusa ludziom różnych kultur, języków i cywilizacji stanowiło wyzwanie już w czasach pierwotnego Kościoła. Podobnie jest i dzisiaj we współczesnym, zglobalizowanym świecie, w którym kolejnym pokoleniom głosi się treść orędzia Jezusa. W tym kontekście warto przytoczyć słowa papieża Franciszka „o «opcji misyjnej», zdolnej przemienić wszystko, aby zwyczaje, style, rozkład zajęć, język i wszystkie struktury kościelne stały się odpowiednią drogą bardziej dla ewangelizowania współczesnego świata, niż do zachowania stanu rzeczy" (EG 27). Przemienianie wspomnianych tu zwyczajów, stylów itd. niewątpliwie nawiązuje do treści głoszenia Ewangelii, do jej serca i istoty, a nie do zewnętrznej szaty słownej. Trudno przecież sobie wyobrazić, aby papież miał tu na myśli oderwany od tradycji przekaz orędzia bądź jego zmianę, gdyż mówi o tym w kontekście tworzenia odpowiedniej drogi dla ewangelizacji. Idzie więc o wypełnienie ich treścią Ewangelii i podanie w odpowiedni sposób.

Uzupełnienie tematu słowami „treść przepowiadania” nie tylko ukierunkowuje badania, ale stanowi próbę podjęcia jednej z ważniejszych kwestii związanych $\mathrm{z}$ głoszeniem Ewangelii, która pojawiła się od samego początku chrześcijaństwa: jak ją werbalizować, aby w pełni oddać jej treść? Problem przekazu treści nie jest wyłącznie związany z przepowiadaniem Jezusa, ale dotyczy wszystkich informacji przekazywanych na piśmie lub ustnie. Język z natury swojej jest historyczny i niejednoznaczny. Problem ten łączy się z tym, co w XX wieku określono mianem inkulturacji, która obejmuje nie tylko religię, ale wszelką ideologię i światopogląd. Inkulturacja - jak twierdzi Jesús Lopez Gay - chce wyrażać głęboki i dynamiczny proces przynależności Kościoła do kultury, obejmujący człowieka z jego wszystkimi wartościami ${ }^{1}$ i zgodnie z ujęciem encykliki Jana Pawła II

1 Por. Pensiero attuale della Chiesa sullinculturazione, w: Inculturazione. Concetti, problemi, orientamenti, Centrum Ignatianum Spiritualitatis, Roma 1979, s. 24; 
(por. RMis, V, 53) dotyczy wszystkich ludów, z którymi Ewangelia wchodzi w kontakt. Dlatego badanie treści głoszonego orędzia Jezusa domaga się uwzględnienia różnorodności osób zarówno je przekazujących, jak i otrzymujących. Problem jest ściśle teologiczny i nie wydaje się, aby współczesna biblistyka, zwłaszcza ta nastawiona na aspekt wyłącznie filologiczny i historyczny, mogła tu wiele pomóc. Dla współczesnego głosiciela może ona stanowić znakomity punkt wyjścia, ale jego właściwym zadaniem niezmiennie pozostaje wyrażenie treści objawionej Ewangelii człowiekowi współczesnemu, nie zaś poprzestawanie na przekazie jedynie czystej wiedzy.

\section{Realia związane z głoszeniem i przyjmowaniem Ewangelii}

Warto pamiętać, że treść przekazywanego orędzia, jak i treść przyjętego nie jest nigdy w pełni weryfikowalna przez człowieka postronnego, bo dokonuje się pomiędzy dwoma podmiotami: głosicielem i jego odbiorcą. Dlatego zarówno w odniesieniu do wspólnoty chrześcijańskiej, jak i pojedynczego człowieka możemy mówić o wzajemnej wymianie inkulturacyjnej. Głosiciel Ewangelii, zanim cokolwiek przekaże, najpierw sam musi przyjąć od ludzi, którym głosi, przynajmniej język i sposób jego rozumienia, a to już stanowi część światopoglądu. Podstawowym zadaniem głosiciela jest przekazanie Ewangelii Jezusa, a nie własnych, nawet najlepszych przemyśleń. Dlatego głosiciel powinien dokonać ekskulturacji orędzia Jezusa ze świata własnej kultury i wartości, aby przekazać innym Ewangelię, a nie swoje zwyczaje czy światopogląd. Zadaniem odbiorcy jest inkulturowanie przyjmowanych treści do rodzimego obszarunorm obyczajowych. W ten 
sposób dokonuje się ewangelizacja świata: świat podlega procesowi chrystianizacji, a chrześcijanie nieraz ulegają pokusie sekularyzacji. Złożoność procesu ewangelizacji wynika ze specyfiki języka ludzkiego, który korzysta ze słów w celu przekazywania informacji. Człowiek posiada czyjś zapisany tekst (lub wygłoszone słowa), ale nie ma treści, która rodzi się w chwili pisania (mówienia), gdy autor nadaje swoim pisanym słowom konkretne znaczenie. Podobnie, treść się rodzi podczas czytania (słuchania), gdy czytelnik słowom kogoś innego nadaje swoje rozumienie. Dlatego treść autora niekoniecznie musi się pokrywać z treścią odbiorcy. Trudno byłoby wykazać, że dwóch ludzi posiada identyczne pojęcie dobra, szczęścia, sprawiedliwości, czy miłości. W relacji głosiciela i słuchacza (odbiorcy) mamy więc dwie zawartości: treść głoszącego i treść słuchającego (czytającego). Dlatego w aspekcie homiletycznym ważne jest nie tylko to, co głosiciel głosi, ale również, jak jest rozumiany. W odniesieniu do treści przyjmowanych poglądów, a więc także i orędzia Ewangelii, św. Tomasz z Akwinu stwierdził, że „quidquid recipitur ad modum recipientis recipitur” ${ }^{2}$ („,cokolwiek się przyjmuje, przyjmuje się na sposób przyjmującego”, a nie dającego).

Złożoność problemu wzrasta, gdy język ojczysty głosiciela jest różny od języka odbiorcy, a jeszcze bardziej gdy dotyczy to ludzi różnych cywilizacji. Wyraził to expressis verbis półtora wieku przed Chrystusem Terencjusz (zm. ok. 159 przed Chrystusem) ${ }^{3}$, pisząc, że „duo cum faciant idem, non est idem” („gdy dwóch czyni to samo, to

2 Summa Theologiae, 1a, q. 75. Kwestię tę św. Tomasz omawiał wiele razy i w różnych wersjach. Ten sposób przyjmujacego obejmuje również wolę słuchacza. Por. W. May, The Different Meanings of Human Acts In the Culture of Life and the Culture of Death - Part 2, https://www.catholicculture.org/culture/library/view. cfm?recnum=8841 (dostęp: 20.9.2015), gdzie pisze o tej formule: „But as we have seen, it is in and through our choices, in particular, choices that can be called "commitments», that we make ourselves to be the «receivers» that we are".

3 Por. Terencjusz Afrykańczyk, Bracia, w: tegoż, Komedie. Eunuch, Bracia, Teściowa, tłum. M. Brożek, Wrocław-Warszawa-Kraków-Gdańsk 1971, s. 208. 
nie jest to samo"), nawet jeśli odnieślibyśmy to do ludzi jednego narodu i języka. Podobnie się dzieje, gdy zamienimy faciant na dicunt, to znaczy "gdy dwóch mówi to samo".

Ponadto zarówno głosicieli, jak i odbiorców różnicuje ich osobowość (zwłaszcza poziom etyczny i intelektualny) oraz, a może przede wszystkim, motywacja głoszenia Chrystusa i motywacja przyjmowania chrześcijaństwa ${ }^{4}$. Pisze o tym wyraźnie św. Paweł, podkreślając, że są ludzie głoszący Chrystusa nawet z zawiści i zazdrości i zapewniając, że cieszy się z tego, iż na wszelki sposób głoszony jest Chrystus (por. Flp 1,15-17). Paweł pisał wprawdzie o motywie głoszenia Jezusa, ale trzeba zapytać, czy motyw przepowiadania może wpływać na głoszone treści. Czy ktoś motywowany chęcią brudnego zysku (używając określenia Pawłowego - por. Tt 1, 7; 1 Tm 3, 8; 1 P 5, 2) nie dostosuje treści orędzia Jezusa do oczekiwań słuchacza w taki sposób, aby osiągnąć swój cel? Czy może się zdarzyć tak, że ktoś próbuje zmieniać treść orędzia, aby się komuś przypodobać lub po prostu przekazywać treści niezgodne z duchem Ewangelii Jezusa? To samo dotyczy odbiorcy, gdy ktoś przyjmowałby je z motywów pozareligijnych. Ten sam Paweł Apostoł, który cieszy się z faktu głoszenia Chrystusa na wszelkie sposoby, za zmianę kerygmatu grozi karą anatemy (Ga 1, 8-9). Podobnie, głosząc bezwzględne pierwszeństwo Chrystusa, karci błędne poglądy dotyczące Jego natury Bożej (por. Kol 1-2, zwłaszcza 2, 6nn), piętnuje błędy związane z wiarą w zmartwychwstanie ciała (por. 1 Kor 15), odmawia przynależności do Chrystusa ludziom pokładającym nadzieję w obrzezaniu ciała (Ga 5, 2), ekskomunikuje Hymenajosa i Aleksandra (por. 1 Tm 1, 18-20) i za odpadłych od prawdy uważa głoszących, że zmartwychwstanie już nastąpiło (por. 2 Tm 2, 1718) itd. Podobnie, autor pism Janowych nazywa antychrystem człowieka negującego Wcielenie Syna Bożego (por. 1 J 4, 2-3). W ten runkowanie głoszenia katechez do młodzieży, "Pro Musica Sacra” 13 (2015), s. 58nn. 
sposób autentyczna treść i rozumienie orędzia Ewangelii przynajmniej werbalnie i zewnętrznie było gwarantowane w obrębie tego, co nazywa się ortodoksją, a odrzucane w formie herezji (por. Dz 5, 17 i inne; 1 Kor 11, 19; Ga 5, 20; Tt 3, 10; 2 P 2, 1). Wypada tu podkreślić, że większość heretyków czytała to samo Pismo Święte, co i głosiciele ortodoksyjni, i powoływała się na te same frazy biblijne, niezależnie od tego, czy czytali je w językach semickich, greckim czy łacińskim. Wynika stąd, że nie idzie o same słowa, ale właśnie o nadawaną im treść. Ona stanowi o prawdziwości, autentyczności i integralności głoszonego orędzia.

\section{Treść głoszonej Ewangelii Jezusa Chrystusa w starożytności chrześcijańskiej}

Zasadniczą treścią chrześcijańskiego przepowiadania jest osoba i dzieło Jezusa Chrystusa. Chrystologię Nowego Testamentu opracował o. Augustyn Jankowski ${ }^{5}$. Jean Daniélou ${ }^{6}$ i ks. Franciszek Szulc ${ }^{7}$ w ramach monografii dotyczących teologii judeochrześcijańskiej zaprezentowali chrystologię judeochrześcijańską. Chrystologię starożytności chrześcijańskiej szczegółowo omawia o. Aloys Grillmeier SJ w dwutomowej monografii o Jezusie Chrystusie w wierze Kościoła ${ }^{8}$, a zwięźle ujmuje ją Jacques Dupuis?

5 Por. A. Jankowski, Rozwój chrystologii Nowego Testamentu, Kraków 2005.

6 Por. J. Daniélou, Teologia judeochrześcijańska, tłum. S. Basista, Kraków 2002, s. 175-315 (Myśl Teologiczna, 39).

7 Por. F. Szulc, Struktura teologii judeochrześcijańskiej, Kraków 2005, s. 161-167.

8 Por. A. Grillmeier, Gesù il Cristo nella fede della Chiesa, t. 1/1-2: Dall età apostal.ica al Concilio di Calcedonia (451), Paideia, Brescia 1982; Christ in the Christian Tradition, t. 2/1: From the Council of Chalcedon (451) to Gregory the Great (590-604), London 1986-1996. Kard. Grillmeier w swoim zawołaniu kardynalskim ma słowa: „Jezus Chrystus jest panem" pisane po grecku: KYPIO $\Sigma$ E $\Sigma$ TIN IE $\Sigma O Y \Sigma$ XPI $\Sigma T O \Sigma$.

9 Por. J. Dupuis, Wprowadzenie do chrystologii, przeł. W. Zasiura, Kraków 1999, s. 99-130. 
Wszyscy oni podkreślają, że Jezus Chrystus jest źródłem i centrum życia Kościoła, teologii i chrystologii. Dlatego przekaz Kościoła pierwotnego można ująć w formule znanej z akrostychu występującego w Oracula Sibyllina: Jezus Chrystus Syn Boży Zbawiciel ${ }^{10}$, który dokonał zbawienia przez swoje Wcielenie, śmierć na krzyżu i zmartwychwstanie. Po grecku pierwsze litery kolejnych słów tworzą wyraz ichthys, który znaczy „ryba”. Wysiłek głosicieli Chrystusa pierwszych wieków sprowadzał się w zasadzie do zachowania integralności tajemnicy Chrystusa objawionej w Nowym Testamencie. Treścią głoszenia był więc Jezus Chrystus w całej Jego tajemnicy życia Bożego i ludzkiego. Treść głoszenia obejmowała $z$ jednej strony aspekt ściśle teologiczny, czyli przekaz prawdy, że Jezus jest Panem, Mesjaszem, Zbawicielem i Bogiem oraz z drugiej strony aspekt ściśle antropologiczny, że każdy człowiek znajduje się w sytuacji potrzeby Zbawiciela, co w chrześcijaństwie określano stanem uwikłania w grzechu (św. Augustyn nazwie go grzechem pierworodnym). Od grzechu i śmierci nie mogą wybawić ani kultura, muzyka, poezja i sztuka ${ }^{11}$, ani wiedza, asceza, żadne dobra materialne i duchowe, ani żadne wysiłki człowieka podejmowane w celu wyzwolenia siebie $z$ takiego stanu rzeczy. Nie pomogą w tym także nawet najpiękniejsze głoszenie i wzruszające homilie, bez względu na ich treść, bo i one nie mają mocy ożywienia martwego ciała, a co dopiero mówić o martwej duszy. Jednakże przekaz autentycznej i integralnej Ewangelii daje możliwość i otwiera przed człowiekiem dostęp do zbawienia. Sposób głoszenia może być pomocny, ale jedynie pod warunkiem, że treścią głoszenia jest Chrystus i Jego orędzie. I tu wyłania się problem treści orędzia Jezusa przekazywanej w różnych szatach językowych.

10 Por. Augustyn z Hippony, O państwie Bożym 18, 23.

11 W moc sztuki wierzono od dawna; np. od V wieku przed Chrystusem rozwija się mit o Orfeuszu - por. G. Sztukiecka, o pocieszeniu, jakie daje mit orficki, w: Świat i Słowo. Filologia, nauki społeczne, filozofia, teologia. Sztuka jako wzór dobrego życia, Bielsko-Biała 2004, s. 43-45. 
Okazuje się, że należało podjąć trud właściwego dobrania nawet określeń imion Jezusa: Mesjasz-Chrystus-Zbawiciel. Podstawową prawdą głoszoną przez Piotra Apostoła jest przepowiadanie, że ukrzyżowany i wskrzeszony Jezus z Nazaretu jest oczekiwanym i zapowiadanym Mesjaszem (Dz 2, 23-36), po hebrajsku mâshîah, „namaszczony”, „pomazaniec Boży”. Tłumacze Septuaginty oddali to słowo greckim terminem świeckim christos. Termin ten w odniesieniu do Jezusa nie został nigdy oddany w języku łacińskim słowem unctus, ale jedynie był transkrybowany christus ${ }^{12}$. Dla wielu Żydów głoszenie Piotra Apostoła dotyczące Jezusa było nie do przyjęcia, ponieważ inaczej wyobrażali sobie Mesjasza. Dla Greków zaś tytuł „Mesjasz” był słowem obcym, oddanym w języku greckim w Nowym Testamencie tak jak w Septuagincie, słowem Chrystus, które od razu stało się imieniem własnym Jezusa (por. np. Dz 9, 34; 1 Kor 8, 6; 2 Kor 13, 3), łączonym nieraz ze słowem Kyrios (por. np. 1 Kor 8, 6; Flp 2, 11), odnoszonym w Septuagincie do Boga.

Poszukiwanie odpowiednich i adekwatnych słów dla wyrażenia tajemnicy Jezusa w świecie nie-semickim nie wypływało z chęci mówcy bycia oryginalnym, ale z konieczności. Domagało się tego już zetknięcie się z kulturą grecką oraz ludźmi, którzy nie wyczekiwali Mesjasza, ani nie posiadali znaczącej wiedzy o istotach zwanych w judaizmie aniołami. Wyrażenie orędzia Jezusa w języku greckim, czyli przetłumaczenie go w praktyce $\mathrm{z}$ myślenia żydowskiego ułatwił znacznie wcześniejszy przekład ksiąg Starego Testamentu na język grecki znany jako Septuaginta (LXX) oraz twórczość żydowskiego myśliciela Filona Aleksandyjskiego (ok. 13 p.n.e. - 41 n.e.), który pierwszy wyłożył myśl biblijną zapisaną w językach semickich w języku greckim. Uważał on między innymi, że Logos biblijny jest tożsamy z Logosem filozoficznym, doskonałym stworzeniem Bożym. Podobnie wyrażali

12 Por. Tertulian, Przeciw Prakseaszowi, tłum. E. Buszewicz i S. Kalinkowski, wstęp H. Pietras, Kraków 1997, s. 82-84 (Źródła Myśli Teologicznej, 4). 
później swoje opinie o Ojcu, Synu i Duchu Świętym niektórzy filozofowie chrześcijańscy, utożsamiając Chrystusa z Synem Bożym, Logosem i Mądrością Bożą, i uznając Go, niestety, za stworzonego lub zrodzonego w czasie. Wszystkie podobne zabiegi stanowiły próby wyrażenia tajemnicy Chrystusa Pana i Boga w języku i mentalności greckiej, które następnie trzeba było długo modyfikować i oczyszczać z błędów, aby wyrazić i zachować integralną treść orędzia zbawienia.

Jacques Dupuis mówi o trzech etapach rozwoju dogmatu chrystologicznego $\mathrm{w}$ pierwszych wiekach ${ }^{13}$. Pierwszy etap dotyczył integralności egzystencji ludzkiej Jezusa Chrystusa i sprowadzał się do odpowiedzi na herezję doketyzmu. Odpowiedź ta przyszła już w czasach apostolskich (udziela jej Nowy Testament), a później wybitni pisarze chrześcijańscy (Ireneusz z Lyonu i Tertulian). Drugi etap dotyczył kondycji boskiej Jezusa przeciwko herezjom: adopcjonizmu, sabelianizmu, arianizmu i innych pochodnych od nich błędów. Przeciwko tym i podobnym poglądom redukującym boskość Jezusa sobory w Nicei (w 325 roku) i w Konstantynopolu (w 381 roku) potwierdziły godność Syna Bożego równą i identyczną z godnością Ojca oraz integralność Jego ludzkiej egzystencji. Trzeci etap dotyczył tajemnicy zjednoczenia natur boskiej i ludzkiej w Jezusie przeciwko ujęciom nestorianizmu, monofizytyzmu, monoteletyzmu i monoenergetyzmu. Jedność osobową Jezusa Chrystusa, że jest w pełni prawdziwym Bogiem i w pełni prawdziwym człowiekiem, potwierdziły sobory: w Efezie (431 rok) - unię hipostatyczną natur w Jezusie, w Chalcedonie (451 rok) - unię hipostatyczną natur w Jezusie bez zmiany, bez pomieszania, bez rozróżnienia i bez rozłączenia, oraz w Konstantynopolu (680 rok) - przynależność woli i działania do natury nie do osoby ${ }^{14}$. Sobór w Chalcedonie stanowi najpełniejsze

13 Por. J. Dupuis, Wprowadzenie do chrystologii, dz. cyt., s. 102.

14 Por. Sobór Efeski, Trzeci list Cyryla do Nestoriusza 4, w: DSP 1, s. 134-135 wraz z notą 54; Sobór Chalcedoński, Definicja wiary 11, w: DSP 1, s. 222-223; Sobór Konstantynopolitański III, Wykład wiary 14, w: DSP 1, s. 318-319. 
rozwinięcie i wyjaśnienie tajemnicy Jezusa Chrystusa, którego naukę dopełnił sobór w Konstantynopolu w 680 roku. Potwierdził to papież Pius XII w encyklice Sempiternus Rex w 1951 roku $^{15}$.

To krótkie zarysowanie rozwoju chrystologii pierwszych wieków ukazuje jak liczne i różnorodne zagadnienia podejmowano, aby w przekazie Dobrej Nowiny chronić integralności egzystencji ludzkiej i boskiej Jezusa Chrystusa. Szczegółowe omówienie nawet jednego z nich wymagałoby obszernej monografii.

\section{Głoszenie Chrystusa a różnice kulturowo- -cywilizacyjne w basenie Morza Śródziemnego w pierwszych wiekach}

Głoszenie Ewangelii pozostaje w ścisłym związku z realiami życia i przekazem żywego i pisanego słowa zarówno głosicieli, jak i słuchaczy. Początki głoszenia Ewangelii obejmowały zasadniczo środowisko diaspory żydowskiej, dając początek wspólnotom judeochrześcijańskim. Chrześcijaństwo rozprzestrzeniało się z Jerozolimy w I i II wieku w trzech kierunkach. Pierwszy wyznaczała trasa do Antiochii, Efezu, Koryntu i Rzymu (Syria Zachodnia, Mała Azja, Grecja, Italia); drugi prowadził poprzez Syrię Wschodnią i Mezopotamię do Persji i Indii; a trzeci do pobliskiego Egiptu. W rezultacie głoszenia Ewangelii we wspomnianych, zróżnicowanych kulturowo i językowo obszarach wytworzyły się w starożytności liczne tradycje liturgiczne obejmujące trzy główne typy liturgii: aleksandryjską, syroantiocheńską i syroorientalną ${ }^{16}$. Współczesne chrześcijaństwo europejskie wywodzi się z nurtu antiocheńsko-koryncko-rzymskiego. Nurt zaś prowadzący do Persji i Indii praktycznie zanikł i tamtejsi współcześni chrześcijanie

15 Tekst w DS 3905 (BF VI nr 76, s. 258n).

16 Szerszy opis pochodzenia poszczególnych wersji liturgii - por. H. Paprocki, Misterium Eucharystii, Kraków 2010, s. 52-91. 
w ogromnej większości są owocem reewangelizacji dokonanej jeszcze w starożytności przez chrześcijan pierwszego nurtu ${ }^{17}$. Dlatego pierwotne chrześcijaństwo starożytne w Mezopotamii i Persji znane nam jest $\mathrm{w}$ zasadzie tylko $\mathrm{z}$ apokryfów.

Z powyższego wynika, że pierwotne chrześcijaństwo zetknęło się i weszło w środowiska kultury perskiej, indyjskiej, semickiej, egipskiej, greckiej i łacińskiej. Interesujące nas chrześcijaństwo w basenie Morza Śródziemnego szerzyło Ewangelię w pierwszych czterech wiekach na obszarze zdominowanym przez kulturę grecką. Proces hellenizacji wzmógł się przed Chrystusem wraz z wyprawami i podbojami Aleksandra Wielkiego. Założona przez niego Aleksandria przy Egipcie należała w I wieku do największych miast w basenie Morza Śródziemnego. Dlatego zrozumienie procesów związanych z głoszeniem Ewangelii w pierwszych wiekach na interesującym nas obszarze wymaga znajomości różnic cywilizacyjnych, zwłaszcza kultury semickiej, greckiej i łacińskiej. W językach semickich zapisano większość ksiąg Starego Testamentu, a judaizm okazał się pierwszym tłumaczem orędzia Biblii na język grecki we wspomnianej już wersji Septuaginty. W synagogach diaspory dominował język grecki, w którym sporządzono wszystkie księgi Nowego Testamentu. Większość ówczesnych chrześcijan czytała po grecku także Stary Testament w wersji Septuaginty. Kościół greckojęzyczny wydał wielkich myślicieli (Orygenes, Klemens Aleksandryjski, Atanazy Wielki, Bazyli Wielki, Grzegorz z Nazjanzu, Grzegorz z Nyssy, Jan Chryzostom) i na soborach pierwszego tysiąclecia sformułował doktrynę chrześcijańską. Od III wieku notujemy na Zachodzie silny rozwój chrześcijaństwa łacińskiego (Tertulian, Hilary z Poitiers, Ambroży z Mediolanu,

17 Por. A. Baron, H. Pietras, Chrześcijaństwo, Kraków 2008, s. 465 oraz A. Feldtkeller, Inkulturation, w: LTK 5, 505-506; szersze omówienie zróżnicowania liturgiczno-kulturowego chrześcijaństwa w pierwszych wiekach na Wschodzie - por. Chrześcijaństwo, s. 466-475. A. Napiórkowski, Teologia XX i XXI wieku, s. 168: „Maronicki Kościół, zachowujący właściwą sobie formę tradycji antiocheńskiej". 
Augustyn z Hippony, Leon Wielki), powstają łacińskie przekłady Biblii (Vetus Itala, Afra, Vulgata). W ten sposób dla pierwotnego chrześcijaństwa na obszarze wokół Morza Śródziemnego najważniejszymi okazały się cywilizacja semicka i grecko-łacińska, zaś językiem głoszenia był język grecki, a później na Zachodzie - łacina.

W odniesieniu do głoszonej treści Ewangelii znaczące są słowa Orygenesa, który zachęca, aby nie tyle zwracać uwagę na zewnętrzną szatę, ile na treść. Pisze on:

Każdy więc, kto dąży do prawdy, niechaj nie dba o nazwy i słowa; bo wśród różnych narodów różne są zwyczajowe znaczenia słów. Niechaj większą zwraca uwagę na to, co jest oznajmiane, niźli na to, jakimi jest oznajmiane słowami, szczególnie na temat spraw tak wielkich i trudnych. Otóż na przykład, gdy się bada, czy istnieje jakaś substancja, przy której nie można pomyśleć o kolorze, wyglądzie, dotyku ani wielkości, a która jest dostrzegalna wyłącznie dla umysłu, każdy nazywa ją, jak chce: Grecy nazywają ją substancją asomatyczną, to znaczy niecielesną, natomiast Pismo Święte nazywa ją substancją niewidzialną. Apostoł bowiem głosi, że Bóg jest niewidzialny, powiada, że „Chrystus jest obrazem niewidzialnego Boga” (Kol 1, 15). Mówi też, że przez Chrystusa zostało stworzone wszystko, „rzeczy widzialne i niewidzialne” (por. Kol 1, 16). Stwierdza w ten sposób, iż także wśród stworzeń istnieją jakieś istoty niewidzialne w swej istocie. One jednak, chociaż same nie są cielesne i chociaż są doskonalsze od substancji cielesnej, posługują się przecież ciałami. ${ }^{18}$

Przytoczone słowa wskazują, że w głoszeniu Chrystusa najistotniejsza jest treść. Mogłoby się nawet wydawać, że według Orygenesa

18 Por. Orygenes, O zasadach IV, 3, 15, tłum. S. Kalinkowski, Kraków, 1996, s. 367 (Źródła Myśli Teologicznej, 1). 
znajomość językoznawcza, filologiczna i gramatyczna nie są w ogóle istotne. Wyraźnie stwierdza, żeby osoba dążąca do prawdy nie dbała, ani nie zatrzymywała się wyłącznie na nazwach i słowach, które w różnych językach mają różne zwyczajowe znaczenia, ale większą uwagę zwracała na to, co jest oznajmiane, a nie na to, jakimi słowami. Nie idzie przecież o literę, ale o ducha orędzia - moglibyśmy powiedzieć, używając Pawłowego określenia (por. 2 Kor 3, 6). To samo można zapewne odnieść do głosiciela Prawdy, że nie są tu istotne słowa, ale treść objawienia, z tym jednak zastrzeżeniem, że głosiciel powinien być świadom - choć często nie jest - że z powodu użycia niewłaściwych słów, odbiorca może błędnie zrozumieć głoszone mu orędzie.

Na przykład, tradycyjnie łączymy serce z uczuciami, a mózg z umysłem. Mówi się też, że kobieta myśli i poznaje sercem, a mężczyzna czuje rozumem. W prefacji chrześcijanie liturgii łacińskiej i jej pochodnych śpiewają „w górę serca”, a Grecy „w górę umysły”, często nie wiedząc, że to, co dla Hebrajczyków oznaczało serce (leb), dla Greków było umysłem (nous), jakkolwiek serce (kardia) było synonimem umysłu (nous) ${ }^{19}$.

Ze względu na język grecki i łaciński pierwszych wspólnot treść orędzia Jezusa docierała w zasadzie do mieszczan. Ludność zaś wiejska zasilała wiele sekt. We Frygii (dzisiejsza Turcja) montaniści głosili orędzie Jezusa w lokalnych językach, w Egipcie mnisi czynili to samo i chrześcijaństwo koptyjskie przetrwało tam do dziś, natomiast Kościół afrykański św. Augustyna, posługujący się językiem łacińskim, bez inkulturowania chrześcijaństwa w językach lokalnych, całkowicie zniknął po inwazji islamu ${ }^{20}$. Przykład ten pokazuje dobitnie, jak

19 Por. Konstytucje aposto/skie VIII, 12, 5 (SCL 2, s. 236 wraz z notą A).

20 L. Padovese, Wprowadzenie do teologii patrystycznej, dz. cyt., s. 172 pisze: „nasuwa się pytanie, jak Kościół tak potężny, tak bogaty w biskupstwa i klasztory, mógł zniknąć tak szybko i całkowicie. Zapewne wiele jest przyczyn upadku. Pomiędzy nimi, być może, nie ma ważniejszej niż rzymski charakter chrześcijaństwa w tym regionie. Ci, których Kościół pozyskał, są zasadniczo Rzymianami posługującymi się językiem łacińskim: od samego początku jego biskupami i kapłanami byli 
ważna jest treść głoszonej Ewangelii, dostosowana do realiów życia słuchaczy, zwłaszcza ich języka. Nie mówimy tu o sposobie przekazu treści, ale o niej samej.

Związek chrześcijaństwa „mieszczańskiego” w świecie greckim $\mathrm{z}$ greką, a następnie $\mathrm{z}$ łaciną, zabezpieczał Kościół przed podziałami i rozdrobnieniem. Luigi Padovese pisze, że „przejście orędzia chrześcijańskiego z jednego środowiska językowego do innego oznacza o wiele więcej, aniżeli tylko formalną zmianę. Niesie z sobą decydującą zmianę zawartości orędzia, na skutek czego stawia pod znakiem zapytania jedność Kościoła w świecie”21. Opozycja pomiędzy Kościołem na Wschodzie i na Zachodzie istniejąca w wieku IV w jakiejś części była skutkiem wzrastającej nieznajomości języka greckiego na Zachodzie i języka łacińskiego na Wschodzie. Wcześniej wspólnym językiem wschodniego świata śródziemnomorskiego była greka i nawet na Zachodzie dopiero od połowy III wieku łacina stała się dominująca wśród chrześcijan zachodnich ${ }^{22}$. W aspekcie indywidualnym poszczególnych wiernych chrześcijaństwo przyjmowane bez znajomości języka głosiciela, sprowadzało się do symboli religijnych i formuł, zachowując wiele z pogaństwa ${ }^{23}$. W aspekcie zaś wspólnotowym prowadziło do różnic wynikających z przeżywania objawienia w różnych językach i jeśli dochodziło do zbyt głębokich zmian, prowadziło to nawet do podziału. Tak stało się w IV i w następnych

łacinnicy; jego liturgia była po łacinie; jego Biblia także była łacińska i nigdy nie pomyślano o przetłumaczeniu jej na język punicki, chociaż istniała - wydaje się literatura punicka. Co najwyżej postarano się załatwić tubylcom kazania w języku punickim, jednakże biskupi i księża zdolni posługiwać się tym językiem, zawsze byli zbyt nieliczni, aby mieć osiągnięcia o znaczącym zasięgu... Czy była w tym zwykła postawa narodowej opozycji wobec cesarstwa? Tak więc nie można się dziwić, że począwszy od wielkich najazdów arabskich, Kościół w Afryce nie przetrwał długo: winny niezapuszczenia dostatecznie głębokich korzeni w ludności tubylczej, zachorował i umarł".

21 Por. L. Padovese, Wprowadzenie do teologii patrystycznej, dz. cyt., s. 177.

22 Por. H. Chadwick, Historia rozłamu Kościoła wschodniego i zachodniego od czasów apostolskich do soboru florenckiego, tłum. P. Sajdek, Kraków 2009, s. 20.

23 Por. L. Padovese, Wprowadzenie do teologii patrystycznej, dz. cyt., s. 178. 
wiekach wśród chrześcijan języka greckiego i łacińskiego. Dla pełni obrazu problemów związanych z głoszeniem Ewangelii w pierwszych wiekach należałoby jeszcze uwzględnić wpływ władz politycznych na treść głoszenia, bo bez wątpienia imperium rzymskie pełniło rolę scalającą chrześcijan, zwłaszcza od panowania cesarza Konstantyna Wielkiego, przez czasy rozpadu imperium na królestwa, aż po reformację i ruchy narodowościowe w XIX i w XX wieku.

\section{Krótka charakterystyka mentalności semickiej (Semitas)}

Mentalność semicką określa się jako dynamiczną ze specyficznym podejściem do historii. Thorleif Boman stwierdza, że odzwierciedla się ona także w języku. Jego zdaniem język hebrajski wyraża semickie pojmowanie świata, całkowicie odmienne od greckiego statycznego ujmowania rzeczywistości ${ }^{24}$. Dynamizm myślenia semickiego i podejście historyczne Franciszek Szulc charakteryzuje następującymi słowami:

W konfrontacji z myślą grecką w pełni ujawnia się dynamiczny charakter mentalności semickiej, której wyrazem jest Biblia. W świecie Biblii wszystko podlega ciągłej zmianie i ewolucji, gdyż najgłębszym źródłem istnienia całej rzeczywistości stworzonej jest Bóg. [...] W historii dokonuje się zbawienie, coś najbardziej istotnego i decydującego dla człowieka - czego nigdy w tej formie nie mogłaby przyjąć umysłowość grecka. Bo też koncepcja historii i czasu jest w Biblii całkowicie odmienna od zapatrywań Hellenów. [...] Sprzyja temu biblijne pojęcie czasu,

24 Por. T. Boman, Das hebraische Denken im Vergleich mit dem griechischen, Göttingen 1968, s. 18nn. 139; por. także F. Szulc, Struktura teologii judeochrześcijańskiej, Kraków 2005, s. 135. 
który nie jest niezmienną miarą wszechrzeczy - greckim chronosem - ale jest związany z wydarzeniami, które go treściowo określają, stąd na wydarzenie w historii zbawienia używa Biblia terminu kairos. Świadomy dobór własnej terminologii potwierdza jeszcze bardziej odrębność biblijnego i greckiego pojmowania świata. ${ }^{25}$

Ponadto całą literaturę biblijną cechuje ujmowanie binarne zagadnień. Niewątpliwie upraszczało ono rzeczywistość, ale równocześnie porządkowało ją i ustawiało na horyzoncie aksjologicznym i eschatologicznym: niebo-piekło, prawda-fałsz, światłość-ciemność, życieśmierć, droga wąska-droga szeroka. Chociaż świat grecki nie lubował się w skrajnym ujmowaniu rzeczywistości, to dopiero w języku łacińskim miejsce oczyszczenia duszy po śmierci określono nazwą purgatorium, czyli czyściec ${ }^{26}$. Jest to o tyle interesujące, że pojęcie oczyszczenia było wspólne niemal dla wszystkich religii, zwłaszcza dla judaizmu. Podobnie, platonicy i neoplatonicy, ponieważ przyjmowali pogląd o wieczności duszy, nie potrzebowali rozwijać idei semickiego szeolu ani gehenny dla zachowania osobowej tożsamości przed i po śmierci człowieka.

W świecie semickim i greckim żywa była symbolika skały i światła. W Starym Testamencie (por. Hi; Ps; Iz; Mdr) i w Nowym symbole te wzajemnie się uzupełniają: Jezus mówi, że tylko dom zbudowany na skale jest trwały (por. Mt 7, 24-25); że na skale zbuduje swój Kościół (Mt 16,18), ale mówi także o synach światłości (Łk 16, 8), o tym, że chrześcijanie są światłem świata (por. Mt 5,14). W praktyce jednak po dwóch tysiącach lat Żydzi na grobach bliskich zostawiają małe

25 F. Szulc, Struktura teologii judeochrześcijańskiej, Kraków 2005, s. 135-137.

26 O czyśćcu por. Sobór w Bazylei-Ferrarze-Florencji-Rzymie, Florencja, Bulla unii z Grekami 14, w: DSP 3, s. 471-473 nota 33; dyskusja teologów o czyśćcu por. Concilium Floretinum Documenta et Scriptores, Roma 1940, VIB, s. 225-231 oraz VIII/2A, Roma 1968. 
kamyczki, a chrześcijanie zapalają świece (chociaż synod w Elwirze, sprzeciwiając się zwyczajom pogańskim, ograniczał palenie świec na cmentarzu ${ }^{27}$ ) i w wyznaniu wiary powtarzają słowa: „światłość ze światłości”, które znajdujemy już u Filona Aleksandryjskiego, a później i u Plotyna ${ }^{28}$.

Cechą charakterystyczną myślenia semickiego jest kompozycja opierającą się na koncentrycznym podawaniu paralelnych i symetrycznych członów. Opracował ją pokrótce Rolland Meynet. Jej wpływ na treść głoszonego orędzia rodzi się z jednej strony poprzez umieszczanie najważniejszych treści w środku symetrycznych paralel (np. modlitwa Ojcze nasz, ewangelie itd.) ${ }^{29}$. Z drugiej zaś strony odczytywanie tak zapisanego tekstu semickiego w świecie greckim bez uwzględniania wspomnianej specyficznej kompozycji nieuchronnie prowadzi do innej interpretacji tego samego tekstu (por. np. KKK 2803-2806).

Podobnie rzecz się ma z pojęciem Logosu, ważnym dla chrześcijaństwa już choćby z powodu Prologu Ewangelii według św. Jana, które wyrasta z pradawnej tradycji judaistycznej i z równie dawnej filozofii greckiej, a w objawieniu pojawia się w Septuagincie. Syntezy koncepcji filozoficznej i biblijnej Logosu jako pierwszy dokonał Filon Aleksandryjski, a od niego przejęli ją pierwsi chrześcijanie. Logos w myśli filozoficznej i teologicznej opracował o. Damian Mrugalski ${ }^{30}$. Omawia on między innymi zakresy znaczeniowe greckiego słowa logos oraz hebrajskiego dabar. Ostatnie słowo obejmuje element dianoetyczny, czyli najogólniej mówiąc intelektualny, związany z poznaniem i wiedzą (obecny w myśli greckiej i hebrajskiej) oraz element dynamiczny (wyłącznie hebrajski), wskazujący na moc i skuteczność

27 Por. Elwira (ok. 306), kan. 34 (SCL 1, 55).

28 Por. Nicea (325), Wyznanie wiary, w: SCL 1, 25 nota 2.

29 Por. R. Meynet, Wprowadzenie do hebrajskiej retoryki biblijnej, Kraków 2001, s. 12-13.

30 Por. D. Mrugalski OP, Logos. Filozoficzne i teologiczne źródła idei wczesnochrześcijańskiej, Kraków 2006. 
każdego Bożego Dabar, które zawsze się wypełnia ${ }^{31}$. Wyraźnie widać, że nie idzie tu o samo słowo logos ani o jego greckie znaczenie, ale rzeczywiście o jego treść, bo ona kształtuje istotnie rozumienie Wcielenia i innych prawd dotyczących Boga. Nic więc dziwnego, że wspominany już Orygenes, objaśniając zdanie J 1, 1 poświęcił aż 50 stron wyjaśnieniu tego słowa ${ }^{32}$.

Koncepcja Logosu w połączeniu z odmiennym ujmowaniem cielesności w świecie semickim i w świecie greckim znajdowała swoje odzwierciedlenie w chrystologii. Pierwotna chrystologia typu Logos-sarx (Słowo stało się ciałem - J 1, 18) szybko uległa rozwojowi w świecie greckim, w którym określenie, że „Słowo stało się ciałem” dla Greka nie było wystarczające, aby wyrazić prawdę o zjednoczeniu Syna Bożego z całym człowiekiem. Dlatego chrystologia typu Logos-sarx przeszła w chrystologię Logos-anthropos i zamiast o wcieleniu (sesarkomene) mówiono o wczłowieczeniu (enathropesis) Syna Bożego. Ponadto, pierwotna wspólnota chrześcijan stanęła przed trudem dopracowania chrystologii wzorowanej na angelologii. Dla judeochrześcijan chrystologia oparta na angelologii nie stwarzała żadnych trudności, ponieważ Bóg właśnie pod postacią aniołów odwiedził Abrahama (por. Rdz 18, 1nn: wizyta trzech mężczyzn), a w świecie greckim była równoznaczna z odmówieniem Jezusowi pełnego bóstwa (jeśli jest aniołem, to nie jest Bogiem). Rzecz znamienna, że Arystydes, filozof ateński i apologeta z II wieku uważał, że Żydzi wierzyli w aniołów ${ }^{33}$. Nie ważne tu jest w ogóle to, czy uważał tak na podstawie osobistej lektury dzieł z judaizmu czy innych greckich myślicieli. Pokazuje to, jak w rzeczywistości następuje recepcja poglądów stosownie do

31 Por. D. Mrugalski OP, Logos..., dz. cyt., s. 74-75.

32 Por. Orygenes, Komentarz do Ewangelii św. Jana, tłum. i oprac. S. Kalinkowski; wstęp H. Pietras, Kraków 2003, I, 103 - II, 69, s. 47-97, (Źródła Myśli Teologicznej, 27).

33 Por. Arystydes, Apologia, w: Pierwsi apologeci greccy, tłum. L. Misiarczyk, Kraków 2004, s. 14 (Biblioteka Ojców Kościoła, 24). 
wspomnianej powyżej zasady św. Tomasza: „quidquid recipitur ad modum recipientis recipitur".

\section{Krótka charakterystyka mentalności greckiej (Graecitas) i łacińskiej (Latinitas)}

Mentalność grecką w przeciwieństwie do semickiej określa się jako statyczną, ześrodkowaną na prawdach ogólnych, a nie opierających się na wydarzeniach historycznych, które w życiu człowieka i świata cechuje po prostu cykliczność. Franciszek Szulc stwierdza, że dla Greka „prawdziwa wiedza może dotyczyć tylko wiecznych i niezmiennych prawd, natomiast na temat zmiennej rzeczywistości, która jest chwytana przez nasze zmysły, możemy tworzyć tylko mniemania [...] nie ma miejsca na wiedzę historyczną, na wiedzę o konkretach i zdarzeniach zachodzących w czasie. Gromadzenie informacji o empirycznych faktach i jednostkowych wydarzeniach nie jest jeszcze prawdziwą nauką, bo nie upoważnia do stwierdzenia ogólnych prawd. I chociaż Grecy mieli wybitnych dziejopisarzy w osobach Herodota i Tucydydesa, to jednak nigdy nie przyznali nauce historycznej miana prawdziwego poznania i nauka o dziejach nie miała dla nich żadnego znaczenia. Ponadto powszechne było przekonanie o cyklicznym charakterze czasu i historii, zrodzone niewątpliwie z potocznego doświadczenia oraz obserwacji przyrody i ruchu ciał niebieskich. [...] Cykliczny obraz procesów dziejowych [...] nie pozwalał dostrzec w historii jakiegokolwiek sensu [...] wszystko bowiem ogarnia powszechne prawo repetycji” ${ }^{34}$.

Nic więc dziwnego, że w podejściu filozoficznym i statycznym świata greckiego Bóg Abrahama, Izaaka i Jakuba, Bóg Izraela, stał się od razu Bogiem całej ludzkości ze wszystkimi tego konsekwencjami.

34 F. Szulc, Struktura teologii judeochrześcijańskiej, Kraków 2005, s. 133-135. 
Podobnie, grecki logos i gnoza, filozofia rozumiana jako umiłowanie mądrości oraz stoicka harmonia w świecie, prawo naturalne i apoteoza rozumu wpływały na religijne myślenie chrześcijan świata grecko-łacińskiego. W świecie greckim akcent kładziono na gnozę, a Bóg był uważany za prazasadę, absolut, pierwszą przyczynę i dobro najwyższe. Przejawiło się to między innymi u Klemensa Aleksandryjskiego oraz w licznych sektach gnostyckich w pierwszych wiekach, które opisuje Epifaniusz z Salaminy w Panarionie. To właśnie w ten sposób kluczowy w Nowym Testamencie temat wiary, został w świecie greckim uzupełniony - a w wielu przypadkach po prostu wyparty przez gnozę. W tym tkwi źródło dylematów nurtujących teologów na temat relacji wiary do rozumu, które trwają od starożytności poprzez średniowiecze (fides quaerens intellectum) aż do naszych czasów (fides et ratio). Tymczasem novum chrześcijaństwa stanowi proste stwierdzenie, że Bóg jest Miłością (agape) (1 J 4, 8. 16; Łk 7, 47; $\mathrm{J} 3,19)^{35}$ oraz że praktykowanie miłości stanowi pełnię realizacji możliwości i życia religijnego człowieka (por. np. 1 Kor 13).

Podobne różnice i problemy pojawiały się w antropologii opartej na trychotomii (duch-dusza-ciało) i na dychotomii (duszaciało) oraz w ubóstwianiu natury i propagowaniu życia ekologicznego i zgodnego z naturą, lansowanego przez całą filozofię przedplatońską i stoicyzm. Dopiero Platon zmienił zasadę „naśladuj naturę” na zasadę „naśladuj Boga”. Przykład wpływu myśli stoickiej na treść głoszenia widać w wypowiedziach św. Cypriana z Kartaginy, który przyjął chrześcijaństwo jako dojrzały stoik, i głosił, że prześladowanie za cesarza Decjusza przyszło dla oczyszczenia Kościoła, bo kobiety się malowały, a mężczyźni trefili włosy, czyli nie żyli zgodnie z naturą, a więc według stoika popełniali grzech ${ }^{36}$.

35 Miłość w Biblii omawiają między innymi C. Spicq, A. Nygren, G. Stählin i E. Stauffer; a miłość w czasach patrystycznych - J. Farges, Viller, J. Kirchmeyer, T. Špidlík.

36 Cyprian z Kartaginy, O upadłych 6: „Kapłanom nie dostawało pobożności; w posługiwaniu brakowało im gorącej wiary, w uczynkach miłosierdzia, w obycza- 
Świat grecki rozwinął, prawdopodobnie jak żaden inny, żywe słowo (logos), język mówiony, retorykę jako królową nauk i umiłowanie mówców. Największy rozkwit krasomówstwa przypada na twórczość Demostenesa w IV wieku przed Chrystusem. Kultura grecka od czasu epoki archaicznej była w istocie rzeczy kulturą mówioną, gdzie obowiązywał kult żywego słowa. „W żaden sposób nie możemy spodziewać się tego, iż zrozumiemy poglądy Greków na ich własną literaturę i kulturę, dopóki nie uświadomimy sobie tej szczególnej czci, którą żywili dla utalentowanego mówcy" - jak pisze jeden z najwybitniejszych znawców kultury greckiej Kenneth James Dover ${ }^{37}$. Starożytny świat śródziemnomorski wydał wielkich mówców języka greckiego: Gorgiasza, Lizjasza, Izokratesa, Demostenesa oraz języka łacińskiego: Cycerona i Kwintyliana. Ten ostatni pisze, że Demostenes uchodzi za ustawowo przyjęty wzór sztuki retorycznej ${ }^{38}$. Co to ma wspólnego z treścią głoszenia, skoro jest to raczej sposób i forma głoszenia? Ma jednak wiele wspólnego, bo wypracowane kanony retoryki narzucały określone formy, z których jedne zwracały większą uwagę na perswazję, a inne na prawdę i treść. Wiedza o tym pozwala głębiej rozumieć treść zachowanych mów, a jej brak może prowadzić do fałszywego odczytywania treści. Widać to szczególnie przy zestawieniu utworów semickich z greckimi i z łacińskimi.

Chrześcijanie w starożytnym świecie śródziemnomorskim wydali równie wybitnych mówców i znawców retoryki, wśród których są najwybitniejsi kaznodzieje Bazyli Wielki, Jan Chryzostom, Augustyn

jach karności. Mężczyźni trefili brody, a niewiasty szminkowały się, poprawiały oczy - choć to przecież dzieło rąk Bożych - sztucznie farbowały włosy" (podaję za M. Michalski, Antologia literatury patrystycznej, Warszawa 1975, t. 1, s. 272). Pozytywny i negatywny wpływ filozofii, w tym także stoickiej, krótko omawia L. Padovese, Wprowadzenie do teologii patrystycznej, dz. cyt., s. 131-135. Nawiązaniem do stoickiej idei: im bliżej natury, tym bliżej Boga - jest wyprawa otwartych oczu będąca częścią formacji Ruchu Światło-Życie.

37 Ancient Greek Literature, Oxford 1980, s. 122; podaję za R. Turasiewicz, Wstęp, w: Demostenes, Wybór mów, Wrocław-Warszawa-Kraków 1991, LXIII.

38 Por. Kwintylian, Kształcenie mówcy, tłum. M. Brożek, Wrocław 1951, s. 274. 
z Hippony. Wszyscy trzej byli wielkimi mistrzami słowa żywego. Jana Chryzostoma porównywano do Demostenesa. Ten jeden z najwybitniejszych mówców w dziejach chrześcijaństwa urodził się i wychował w Antiochii, gdzie szczególnie ceniono wybitnych mówców.

Praktykowana przez nich homilia, wywodząca się ze świata semickiego, właśnie w świecie grecko-łacińskim wyraziła się najpełniej i nierozerwalnie złączyła się z przekazem orędzia Ewangelii. Rzecz znamienna, że najwięcej i najdłuższe homilie zachowały się właśnie ze świata grecko-rzymskiego. „Chrześcijańskie kazanie - pisze Erich Auerbach - korzystało z tradycji retorycznej, która przenikała cały świat antyczny [...] prawie dla wszystkich wysłuchiwanie mów było w pierwszym rzędzie rozkoszowaniem się brzmieniem" ${ }^{39}$. Obecnie w świecie opanowanym przez medialny sposób rozprzestrzeniania informacji, żywe słowo okazuje się mniej atrakcyjne, mniej skuteczne i mniej precyzyjne w przekazie treści.

Typowymi elementami świata greckiego są polis i politeia, czyli państwo-miasto, konstytucja, sposób i zasady życia oraz rodzina patriarchalna. W chrześcijaństwie pierwszych wieków można dostrzec radykalizm etyczny o charakterze arodzinnym, charakterystyczny dla pierwotnego judeochrześcijaństwa, który w środowisku greckim przerodził się w patriarchalizm rodzinny, umiarkowano-konserwatywny, z którym Kościół utożsamia się do dziśs ${ }^{40}$. Zwyczaj mianowania biskupów w starożytności chrześcijańskiej wyłącznie w miastach opierał się na greckim systemie polis - nie istniały diecezje personalne. System patriarchalny do dziś obejmuje wspólnoty prawosławne, a mentalność patriarchalna wyczuwalna jest w całym Kościele na Wschodzie i na Zachodzie. Jan Chryzostom w IV wieku głosił, że dla chrześcijan politeię, czyli, jak już wspomnieliśmy, formę współczesnej

39 E. Auerbach, Język literacki i jego odbiorcy w późnym antyku łacińskim i średniowieczu, tłum. R. Urbański, Kraków 2006, s. 33, por. także s. 35. 43nn.

40 Piszę o tym szerzej omawiając Didache - por. A. Baron, Świętość a ideały człowieka, Kraków 2013, 179-188. 
konstytucji, napisali ewangeliści ${ }^{41}$. W ten sposób Chryzostom podkreśla, że Ewangelia jest dla chrześcijan najważniejszym dokumentem stanowiącym o sposobie ich życia. Jest to znakomity przykład objaśniania ludziom treści słów religijnych (w tym przypadku Ewangelii) z pomocą znanych im słów z języka codziennego.

Podobną funkcję w odniesieniu do treści pełniło rozwinięte w I wieku przed Chrystusem w filozofii greckiej tzw. myślenie egzegetyczne, którego istota sprowadza się do wyjaśniania myśli w konfrontowaniu jej z niepodważalnym autorytetem, który wówczas dla myślicieli greckich stanowiły pisma Platona i Arystotelesa ${ }^{42}$. W starożytnej twórczości chrześcijańskiej zauważamy, że prezentuje ona właśnie typ greckiego myślenia egzegetycznego, w którym niepodważalnym autorytetem jest Biblia ${ }^{43}$.

Przejęcie greckiego myślenia egzegetycznego i jej form wyrażania myśli przez chrześcijan - za pośrednictwem Filona Aleksandryjskiego, który je podjął i podobnie zaczął objaśniać Stary Testament zaowocowało dążeniem do stworzenia kanonu Nowego Testamentu.

41 Por. Jan Chryzostom, Homilie na Ewangelię wg św. Mateusza, cz. I, 4-6, tłum. J. Krystyniacki, uwspółcześnienie tekstu E. Buszewicz, rewizja, oprac. i przypisy A. Baron, Kraków 2000, s. 21-23 (Źródła Myśli Teologicznej, 18); szerzej na ten temat pisze J. Iluk, Żydowska politeja i Kościół w Imperium Rzymskim u schyłku antyku, Gdańsk 2006.

42 Szerzej na ten temat piszę w: Neoplatońska idea Boga a ewangelizacja, Kraków 2015, s. 38-45, gdzie podaję przykłady takiego myślenia: Czy można twierdzić, że świat według Platona nie ma początku, skoro mówi on, o jego budowniczym? Czy można mówić, że świat nie ma początku, skoro w Księdze Rodzaju czytamy, że na początku Bóg stworzył niebo i ziemię (por. Rdz 1, 1)? „Stworzył Bóg człowieka na swój obraz" (Rdz 1, 27): czego dotyczy to podobieństwo (por. Rdz 1, 26): ludzkiego ciała czy duszy? Czy człowiek może pochodzić od małpy na drodze ewolucji, skoro Pismo Święte mówi, że Bóg stworzył człowieka na swój obraz i podobieństwo? itd.

43 Por. Orygenes, Homilie o Księdze Rodzaju 1, 1, tłum. S. Kalinkowski. Warszawa 1984, s. 21 (Pisma Starochrześcijańskic Pisarzy, t. 31, z. 1); Orygenes, komentując słowa Rdz 1, 1: „Na początku Bóg stworzył niebo i ziemię”, pytał: „co jest początkiem wszystkiego?". Odpowiadając, że początkiem jest Chrystus i Zbawiciel, stwierdza, że w Chrystusie zostało stworzone niebo, ziemia oraz wszystko, co zostało stworzone. 
Forma nie tyle zdominowała treść, bo rugowano czyste sofistyczne spory, ale miała wyznaczać granice ortodoksji i ortopraksji. I słusznie, ale problemy z treścią objawienia pojawiały się głównie przy zmianach światopoglądowych związanych z nowymi odkryciami czy teoriami. Jaką na przykład nadać treść słowom, że zatrzymało się słońce (por. Joz 10, 12), pisanym setki lat przed Kopernikiem przez człowieka proszącego Boga o przedłużenie dnia, a czytanym kilkaset lat po Koperniku, gdy współczesny człowiek, aby osiągnąć podobny cel, prosiłby raczej o zatrzymanie ziemi wokół własnej osi? Treść tych wierszy z Księgi Jozuego można sprowadzić do prostych twierdzeń, że Bóg mówi do człowieka jego językiem, że nie ma możliwości nieporozumień itp. Podobne zdanie można formułować w odniesieniu do innych teorii, np. Darwina. Przykłady te pokazują dobitnie, jak nadawana słowom treść jest zawsze wypadkową znajomości języka i posiadanego światopoglądu.

Ponadto, w podejmowaniu problemu treści warto pamiętać, że chrześcijaństwo grecko-, a później także łacińsko-języczne przejmowało wyłącznie terminologię religijnie neutralną, odwołując się do całości hellenistycznego dorobku kulturalnego. Przyjęto słowa ecclesia, katholikos, terminy związane z językiem filozoficzno-etycznym: hairesis, apatheia, askesis oraz religijno-misteryjnym: eusebeia, theosebeia, consecratio, orare, sanctus, ale całkowicie rugowano określenia techniczne religii pogańskich, bo terminy religijne trudno tracą swoje znaczenie, a zwiększają niebezpieczeństwo synkretyzmu ${ }^{44}$.

Język ludzki i sztuka pisania stanowią elementy światopoglądu człowieka i kształtują jego wyobraźnię ${ }^{45}$. Greka i łacina są językami alfabetycznymi samogłoskowymi w przeciwieństwie do spółgłoskowych języków semickich. Greckie to gramma, posiadające różne

44 Por. L. Padovese, Wprowadzenie do teologii patrystycznej, dz. cyt., s. 180.

45 Pisma chińskiego uczą się ludzie kilkanaście lat i dlatego stają się mistrzami odtwarzania. 
znaczenia (m.in. „litera”, „napis”, „pismo”, „dzieło” itp.), pierwotnie oznaczało „malowanie”, „obraz”. Stąd w świecie greckim obrazowy sposób mówienia stał się ulubiony. Mówca, w tym również głosiciel Ewangelii, podobnie jak malarz dysponujący całym płótnem i mogący bez końca coś na nim domalowywać, rozwijał swoją myśl, jakby malował obraz, czego przykładem są homilie św. Jana Chryzostoma. Tymczasem język łaciński określa dzieło pisane mianem textum od texo, texere, czyli „tkam”. Tkaninę należy od razu całą przemyśleć, bo tkacz nie posiada możliwości powrotu do utkanej już części. W ten sposób na poziomie nazewnictwa związanego z mówieniem i pisaniem pojawiają się różnice pomiędzy tym, co określamy tu przez graecitas i latinitas. Przemyślana w całości kompozycja i treść stanowi jeden z wyznaczników latinitas. Równie ważna dla twórczości łacińskiej okazała się zaczerpnięta z myśli stoickiej apoteoza rozumu (wszystko jest dostępne dla umysłu ludzkiego) oraz podejście prawne, a nie mistyczne, nawet w ujmowaniu relacji człowieka z Bogiem (np. grzech i kara; zadośćuczynienie przez krzyż Jezusa). W ten sposób chrześcijaństwo zachodnie zostało narażone na wyzucie się z roli mysterium $\mathrm{w}$ religii i ambiwalentne lub nawet lekceważące podejście do mistyków. Tymczasem uczniowie Jezusa głosili prawdę o zbawieniu, które już tu na ziemi może stać się udziałem każdego, kto w Niego uwierzy i zechce wejść w tajem-

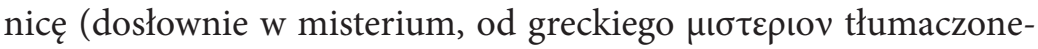
go później na język łaciński przez mysterium np. w 1 Kor 15, 51 lub przez sacramentum np. w Ef 1, 9). Słowo „sakrament” zapożyczono z języka wojskowego, w którym oznaczało przysięgę na sztandar. Stąd człowiek przyjmujący sakrament chrztu na Zachodzie oddawał się Bogu i przyjmował na siebie, w pewnej analogii do zwyczajów wojskowych, szereg bezdyskusyjnych zobowiązań, na Wschodzie zaś wchodził w mysterium. Na początku była niby ta sama treść, a po wiekach łatwo wyodrębniły się dwa różne podejścia do religijności i praktyk religijnych. 
Oddanie greckiego terminu metanoia (przemiana umysłu i nawrócenie) łacińskim terminem paenitentia ${ }^{46}$ (skrucha, pokuta) może wydatnie zniekształcać ideę chrześcijańskiego nawrócenia, czyli jego treść, ponieważ to co, wyraża słowo paenitentia nie oddaje w pełni znaczenia słowa metanoia. Skoro nawrócenie stanowi o autentyczności życia chrześcijańskiego, to jak mogło dojść do takiego tłumaczenia? W Pasterzu Hermasa, a więc w piśmie, na które powołują się setki zachodnich teologów, wskazując, że mówi o pokucie, słowo metanoia w różnych formach fleksyjnych pojawia się 146 razy. Tłumacząc je na łacinę, nie zadowolono się transkrypcją, ale oddawano je łacińskim słowem paenitentia. Podobnie czyniono w przypadku tekstów biblijnych, jak i innych, od samego początku zniekształcając ideę metanoi, bo paenitentia wyraża tylko jeden jej aspekt. François Louvel OP pisze o tym tak:

Pokuta nasuwa myśl o umartwieniu, lecz metanoia jest czymś całkiem innym niż umartwienie. Dotyczy ona serca bardziej niż ciała, wiąże się z wiarą, nadzieją i miłością w nie mniejszym stopniu niż ze sprawiedliwością. Pokuta to nakaz dla człowieka, metanoia jest przede wszystkim uświadomieniem sobie obecności Boga i Jego sądu. ${ }^{47}$

Oczywiście metanoię można rozumieć jako umartwienie, ale w sensie uśmiercenia dotychczasowego sposobu myślenia i postępowania oraz podjęcia nowego życia według Ewangelii Jezusa, które odmładza ducha, a nie uśmierca. W świecie helleńskim „nawrócenie”

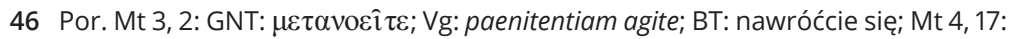

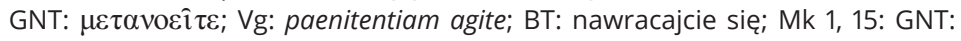

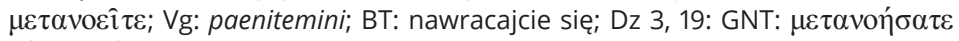

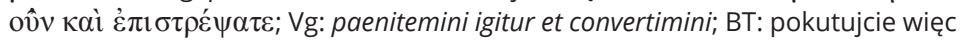
i nawróćcie się.

47 Słowniczek, w: Pierwsi świadkowie, tłum. A. Świderkówna, Kraków 1998, s. 423 (Biblioteka Ojców Kościoła, 10). 
łączyło się z przyjęciem nowej filozofii i związaną z nim zmianą sposobu życia i pojawiło się już u Platona ${ }^{48}$. Współczesny głosiciel Ewangelii może więc stanąć przed dylematem, co głosić: metanoię czy penitencję? Odpowiedź jest prosta: problem Ewangelii nie tkwi w jednym czy drugim słowie, ale w nadawanej im treści. Dla ścisłości warto dodać, że grecka metanoia zawiera pokutę, gdyż greckie Księgi penitencjalne proponują za konkretne grzechy odprawić $20,40,50$, 100 lub nawet 200 metanoi $^{49}$.

$\mathrm{Na}$ Zachodzie teologię bazującą na penitencji (od poena - kara i pokuta) podjął między innymi św. Augustyn w sporze pelagiańskim (Adam po grzechu został ukarany przez Boga śmiercią). Jakkolwiek trzeba uzupełnić, że nie wszyscy na Zachodzie prezentowali tego typu myślenie, bo np. św. Ireneusz uważał, że Bóg ulitował się nad Adamem po grzechu i go uśmiercił, aby go wskrzesić na nowo do życia szczęśliwego.

\section{Zakończenie}

Nie ulega wątpliwości, że treść stanowi o istocie głoszenia Jezusa Chrystusa i Jego Ewangelii. Ważniejszy jest duch niż litera, jakkolwiek i ona jest nośnikiem treści. Pierwotne wspólnoty Kościoła skupiały swoje przepowiadanie na przekazaniu tajemnicy Osoby Jezusa Chrystusa i zachowaniu pełnej integralności objawionej prawdy o Jego prawdziwym bóstwie i prawdziwym człowieczeństwie. Czynili tak, dzieląc się z innymi swoimi przekonaniami o Jezusie oraz działając przeciwko najróżniejszym błędom chrystologicznym powstającym

48 Por. W. Jaeger, Wczesne chrześcijaństwo i grecka paideia, przekł., red. i wprow. K. Bielawski, Bydgoszcz 2002, s. 31.

49 Por. Księgi penitencjalne, Kraków 2011, s. 484 w. 23; s. 487-492, gdzie grecka metanoia jest oddawana po polsku przez "nawrócenie" oraz w przypadku wskazywania na praktyki pokutne "metania". 
od czasów apostolskich. Za główne herezje tego typu z pierwszych wieków uważa się współcześnie doketyzm, ujmowanie zmartwychwstania w kategoriach czysto duchowych bez ciała, subordynacjonizm, adopcjonizm, monarchianizm, arianizm, koncepcje chrystologiczne Marcelego i Bazylego z Ancyry, Apolinarego z Laodycei, monofizytyzm, monoteletyzm i monoenergetyzm.

Analiza treści głoszonego orędzia Jezusa w pierwszych wiekach poświadcza adaptację językowo-pojęciową przy przejściu najpierw ze środowiska semickiego do greckiego, a następnie z greckiego do łacińskiego. Adaptacja ta dotyczyła całości objawienia łącznie z kluczowymi dla chrześcijaństwa terminami hebrajskimi i aramejskimi. Hebrajskie słowo Mesjasz wyrażono greckim Christos oraz łacińskim Christus, nigdy nie tłumacząc go łacińskim unctus. Dla Greków termin Christos stał się imieniem własnym Jezusa. Dodatkowo, określano Jezusa terminem Kyrios, który w Septuagincie odnoszono do Boga, oraz pojęciem Soter z hellenizmu, które weszło do objawienia Nowego Testamentu właśnie w odniesieniu do Jezusa jako Zbawiciela.

Głosiciel Ewangelii z jednej strony powinien dobrze znać swoją kulturę i język, a z drugiej strony nie może mu być obca kultura i język osób, którym ją głosi. Język ludzki w swej warstwie semantycznej nie jest tylko zbiorem informacji, ale odzwierciedla sposób myślenia i światopogląd człowieka. Dzieła patrystyczne stanowią dla teologa pierwszorzędne źródło do poznania treści głoszenia orędzia Chrystusa w różnych językach ludziom różnych kultur i cywilizacji. Ponadto nie bez znaczenia jest i to, że ogromna ich większość powstała ze względów pastoralnych na potrzeby głoszenia Ewangelii. Trzeba jednak pamiętać, że głoszone w nich treści zostały wyrażone przez pryzmat ich własnego języka i światopoglądu.

W świecie śródziemnomorskim w starożytności chrześcijańskiej mamy trzy cywilizacje: semicką, grecką i łacińską, które wyraziły w swoich językach objawienie Boże i przekazały orędzie Jezusa, 
czytane w ich wersjach językowych w Europie do dziś. Świat semicki podchodzi do objawienia w sposób dynamiczny i ściśle związany z historią człowieka i ludu. Wyraża je, ograniczając się do ukazania drogi, którą należy iść i wytyczenia jej przy zastosowaniu metody binarnej i egzegetycznej oraz koncentrycznej kompozycji treści. Człowiek powinien żyć dokładnie według wymagań Boga, bo zawarł z Nim przymierze, które albo wypełni, albo się mu sprzeniewierzy. W zasadzie nie ma miejsca na żaden relatywizm.

Hellenista dąży do odkrycia ogólnych i niezmiennych praw rzeczywistości i tak samo podchodzi do objawienia. Przeprowadza słuchacza przez całe rozumowanie, którego głównym celem są wnioski i precyzyjne definicje. Stąd w uprawianiu teologii w chrześcijaństwie greckim pojawiła się silna tendencja do dogmatyzowania prawd religijnych oraz szczególny nacisk kładziony nie tylko na ortopraksję, ale przede wszystkim na ortodoksję. Podejście takie pociągnie za sobą zmiany w głoszeniu i to zarówno pod względem formy, jak i treści. Religijność zaś nadal - wcześniej pogańska, a później chrześcijańska - będzie się opierała na polis oraz na strukturze patriarchalnej i rodzinno-domowej (oikos). Treść głoszenia zostaje wyraźnie połączona z myśleniem ikonicznym i egzegetycznym, charakteryzującym świat grecki. Świat łaciński uzupełni podejście greckie o aspekt prawny, tworząc religijność opartą na objawieniu i życiu zgodnym z przykazaniami Bożymi, bardziej obwarowanymi, w praktyce niezmiennymi normami prawa Bożego, aniżeli Jego wolą.

Studium pokazuje granice treści, w których musi się poruszać głoszący Jezusa Chrystusa i Jego Ewangelię, aby przekaz objawienia był integralny, a zarazem dla ludzi danej cywilizacji czytelny i mogący przemieniać ich sposób myślenia. Dlatego można wyciągnąć wniosek, że zachowanie integralnego objawienia Ewangelii Jezusa wymaga wyrażenia jej treści nie w jednej niezmiennej formie werbalnej, zabsolutyzowanej abstrakcji jakiegokolwiek języka, ale każdorazowo powinno być „wcielane” w życie konkretnego człowieka 
i dla niego werbalizowane w jego języku i w świecie jego wartości. Dzieje się tak dlatego, że Ewangelia nie jest tylko zbiorem wiedzy do zdobycia na temat działalności proroków, apostołów i Jezusa, ale przede wszystkim jest orędziem do podjęcia własnej metanoi, czyli nawrócenia, skutecznej i trwałej zmiany życia stosownie do woli Bożej.

Analiza dotyczyła wyłącznie głoszenia Ewangelii w formie werbalnej. Trzeba pamiętać, że poznanie pojęciowe stanowi mały procent wiedzy i doświadczeń człowieka. Dlatego warto pomyśleć o opracowaniu również pozawerbalnych sposobów przekazu treści Ewangelii. Ponadto, jeśli treścią głoszenia jest integralna prawda o Chrystusie, to rzeczywiście pojęciowo można wyrazić niewiele, ale wystarczająco, aby człowieka poruszyć do dążenia do zjednoczenia z Tym, który jest Alfą i Omegą dla każdego człowieka i całego świata.

\section{Głoszenie Chrystusa i jego recepcja w starożytności i dziś w aspekcie przepowiadanej treści}

Streszczenie

Istotą przepowiadania Kościoła pierwotnego była osoba i dzieło Jezusa Chrystusa. Jednakże Ewangelia została napisana po grecku przez ludzi wywodzących się ze świata semickiego. Później zaś tekst Ewangelii został przełożony na łacinę. Był więc ukształtowany przez trzy cywilizacje: semicką, grecką i łacińską. Zasadniczym problemem jest więc przekaz Bożego objawienia za pomocą współczesnych języków przy zachowaniu istoty Ewangelii. Problem ten jest zilustrowany na przykładzie słów: Mesjasz, Chrystus, metanoia, paenitentia.

Słowa kluczowe

przepowiadanie, świat semicki, grecki i łaciński, semantyczne aspekty przepowiadania 


\section{Semantic Aspect of Preaching Christ and its Reception in Ancient Christianity and Today}

Summary

This paper deals with the semantic role of preaching the Gospel among people of different languages and civilizations. In the beginning the author describes the contents of the Gospel preached in the first centuries. The essence of the preaching was Jesus Christ himself. But the Gospel was written in Greek by people from a Semitic world and later translated into Latin. There are three different civilizations. The author briefly presents the background of all of them using the scheme: semitas, graecitas and latinitas. The basic problem is: how to express God's revelation while preserving the essence of the Gospel message in many different languages today. Examples of the words: Messiah, Christ, metanoia, paenitentia and so on are given.

Keywords

preaching, Semitic, Greek, and Latin world, semantic aspect of preaching

\section{Bibliografia}

Auerbach E., Język literacki i jego odbiorcy w późnym antyku łacińskim i średniowieczu, tłum. R. Urbański, Kraków 2006.

Baron A., Cultura animi w myśli greckiej (platonizm, arystotelizm, epikureizm, stoicyzm, medio- i neoplatonizm), red. S. Stabryła, Kraków 2015, s. 95-129, (Prace Komisji Filologii Klasycznej PAU, nr 46).

Baron A., Neoplatonizm a chrześcijaństwo w pierwszych wiekach, w: Wczesne chrześcijaństwo a religie, red. I. Ledwoń OFM, M. Szram, Lublin 2012, 425-454.

Baron A., Neoplatońska idea Boga a ewangelizacja. Analiza anonimowego komentarza do „Parmenidesa" Platona na tle myśli plotyńsko-porfiriańskiej, Kraków 2005.

Baron A., Świętość a ideały człowieka (Ojcowie Apostolscy, Klemens Aleksandryjski, Orygenes). Studium teologiczne na tle modeli filozoficzno-religijnych, Kraków 2013.

Baron A., Pietras H., Chrześcijaństwo, w: Religie starożytnego Bliskiego Wschodu, red. K. Pilarczyk, J. Drabina, Kraków 2008, s. 447-521. 
Chadwick H., Historia rozłamu Kościoła wschodniego i zachodniego od czasów apostolskich do soboru florenckiego, tłum. P. Sajdek, Kraków 2009.

Daniélou J., Teologia judeochrześcijańska, tłum. S. Basista, Kraków 2002 (Myśl Teologiczna, 39).

Dokumenty Soborów Powszechnych, t. I-IV,wybór tekstów i oprac. A. Baron, H. Pietras, Kraków 2001-2004.

Grillmeier A. SJ, Gesù il Cristo nella fede della Chiesa, t. 1/1-2: Dall età apostolica al Concilio di Calcedonia (451), Paideia, Brescia 1982; Christ in the Christian Tradition, t. 2/1: From the Council of Chalcedon (451) to Gregory the Great (590604), Mowbrays, London 1987.

lluk J., Żydowska politeja i Kościół w Imperium Rzymskim u schyłku antyku, t. 1: Jana Chryzostoma kapłana Antiochii Mowy przeciwko judaizantom i Żydom, Gdańsk 2006.

Jaeger W., Wczesne chrześcijaństwo i grecka paideia, tłum. K. Bielawski, Kraków 2002.

Jankowski A., Rozwój chrystologii Nowego Testamentu, Kraków 2005.

Padovese L., Wprowadzenie do teologii patrystycznej, tłum. A. Baron, Kraków 1994.

Szulc F., Struktura teologii judeochrześcijańskiej. Studium metodologiczne w świetle badań J. Daniélou SJ, Kraków 2005.

Turasiewicz R., Wstęp, w: Demostenes, Wybór mów, przeł. i oprac. R. Turasiewicz, Wrocław-Warszawa-Kraków 1991, III-CXXXII (Biblioteka Narodowa II/15). 